\title{
Is Deployment Desirable? An Examination of National Missile Defense Alternatives
}

\section{By Nathaniel J. Teti}

Abstract: Today, the United States stands alone as the world's sole superpower. Traditionally, this status and the nation's strategic location has served as an effective national defense. However, with the rise of new threats from rogue states, terrorists, and new powers, the United States must determine whether current national defense policy is sufficient in the world's changing political climate. This article examines the possibility of deploying a National Missile Defense system (NMD). The author suggests three policy alternatives and explores the concerns surrounding the issue. The alternatives include maintaining the status quo, implementing a limited program, or full deploying a full NMD system. The author discusses the difficulty in implementing NMD, but suggests that the changing climate calls for action.

The Cold War was a period of certainty and stability. The United States, with its huge markets and productive capacity, controlled the international economy. The East-West Conflict was the dominant security issue. It gave order to the world. The end of the Cold War will make things more difficult for the United States. We will have to adjust to a world of complex situations, shifting allegiances and diplomatic surprises. ${ }^{1}$

In the Post-Cold War era, the United States finds itself in the precarious position of being the world's lone superpower. The United States, as the world's representative for democracy, will face possible threats from insurgent nations and groups voicing ideological opposition. The U.S. Government no longer has the luxury of identifying threats from a select few aggessors. With each passing year, the advent of new technology allows aspiring countries and even subnational actors to obtain nuclear weapons. The individuals that will lead the United States into the next millennium need to be aware

Nathaniel J. Teti is pursuing a Masters of Public Administration from the George Washington University. of the lessons learned from the Cold War. However, these lessons, important as they may be, will not fundamentally enhance our ability to address new threats created by technological accessibility and regional imperialism.

Only a few countries in the world, until a decade or so ago, were capable of launching an intercontinental ballistic nuclear missile attack. Of the declared "nuclear states," the United States and the Soviet Union were the only nations capable of devastating the entire world with their immense stockpile of weapons. The nascent Cold War prompted a staggering arms race where mutual deterrence became the de-facto national security policy for both nations. An attack by either side would have resulted in levels of destruction unparalleled in the history of warfare. The fear of this devastation ultimately provided a modicum of stability in the increasingly dangerous relationship.

At the outset of the 21st century, in a post-Cold War era, United States defense policy has become increasingly complicated to administer. The Soviet Union no longer exists; for the immediate future, the United States is the world's sole superpower. However, the political global environment is shifting, and new threats from powerful military nations are increasing.

Although the United States possesses a technologically advanced military force, the nation may be more susceptible to attack now than at the height of the Cold War. The scope of warfare in the last decade has changed dramatically, Recalcitrant nations can attack the United 
States from thousands of miles away, rendering natural borders obsolete. The Atlantic and Pacific oceans once created a significant geographical barrier for U.S. defense, but these barriers are quickly shrinking because of missile deliverance capabilities. Eventually, physical distance will no longer impair a missile attack.

The central argument of this article is that the United States must form strategies that combine an introspective examination of past policies and a visionary perspective in forming new objectives. The 1972 Anti-Ballistic Missile (ABM) treaty has served as a fundamental guide for U.S. nuclear weapon policies and has impeded the spread of nuclear weapons. The ABM treaty set the stage foror the preservation of world peace during the Cold War through bilateral arms reductions. Unfortunately, the $A B M$ treaty does not provide safeguards against rogue states, terrorists, or countries with the new desire to build a nuclear force. Potential threats from these nations could jeopardize the future of non-proliferation efforts between the United States and Russia. These burgeoning threats have led the Department of Defense to contemplate the construction of a National Missile Defense (NMD) system. The incoming administration must evaluate the need for this type of defense, and determine whether it would jeopardize U.S. relations with Russia and other countries. These questions need to be addressed by the next administration, and will be discussed in this analysis.

\section{The National Missile Defense Debate}

The idea of providing our country with a defense from missile attacks is not a new one. President Reagan, who in the 1980s was responsible for maintaining the United States' extensive nuclear arsenal, envisioned a missile shield that could protect the United States from a Soviet attack. The "Star Wars" program, although not technologically possible at the time, gave credence to the 44 prospect of building a sustainable missile defense system. In 1994, Newt Gingrich and the Republican Party won the majority in the House of Representatives using the "Contract with America" as the cornerstone of their policy agenda. Within the 10 provisions set forth in the "Contract," one was named the National Security Restoration Act. This plan advocated a renewal of the U.S. missile defense program. The National Defense Authorization Act of 1997 established a bipartisan commission to assess the current and future threat to the United States posed by missile attack. The commission, chaired by former Secretary of Defense Donald Rumsfeld, evaluated the missile deliverance capabilities of rogue nations and concluded that the United States was not as impervious to attack as a 1995 National Intelligence Report indicated. During that time, the North Korean government conducted a missile test that demonstrated they were close to creating a weapon capable of reaching the continental United States, previously a capability thought to be years from deployment. Such developments made it readily apparent to policy makers that a change was needed to safeguard the country against possible attack.

The 2000 Presidential elections have promoted continued debate on how the next administration should deal with pressing defense issues. These issues include questions about how the United States will: 1) provide for the defense of its citizens against hostile nations; 2 ) continue its leadership role in advancing the current global trend toward nuclear non-proliferation; and 3) promote these seemingly contradictory interests while preserving the sovereignty and status as a "superpower." The incoming administration should have the conviction to take the necessary steps for maintaining a strong national defense, whether or not it involves the deployment of a national missile defense system. On July 22, 1999, President Clinton signed into law the National Missile Defense Act of 1999. The law stated that the United States 
IS DEPLOYMENT DESIRABLE?

should deploy a national missile defense. However, it remains unclear how this law will be translated into policy.

\section{Policy Proposals}

When designing new defense policies, the U.S. Government must take the following into account: growing threats to national security, the maintenance of technological "superiority," and the responsibility for leading global nuclear non-proliferation efforts. The government has to acknowledge every conceivable global consequence of deploying a missile defense system. Such a system should only be deployed if every other option to maintaining current security is exhausted. Once this crucial decision has been made, there is no turning back.

It is likely that the U.S. Government will continue to invest money in the research and development of possible alternatives. Policymakers should proceed with caution, in order to avoid impetuous decision-making. This cautionary approach should involve a broad range of considerations that reflect the complexity and interconnectedness of the issues surrounding security policy. It is with this in mind that each defense policy identified in this analysis will be evaluated according to: its effect on national defense (with respect to the current and projected threat), the budgetary implications of the alternative, its effect on non-proliferation efforts (encompassing potential reactions by other nations), the administrative and technological feasibility of the policy, and its political ramifications. It should be noted that this analysis is performed primarily through qualitative reasoning, and is limited by the availability of quantitatively defined information. In preparing this analysis, the lack of well-defined quantitative data often prompted subjective, carefully constructed analysis. This discussion is not intended to be a comprehensive analysis of all the possible defense options available to the government.
However, it can serve as a model to effectively evaluate certain national security policies.

National Defense Impact. Any proposed defense policy must address the affect it will have on national defense, both short-term and long-term. The short-term will be the period before the deployment of defense measures, while the long-term will consist of the years following the procurement and implementation of a national missile defense system. Because of the time constraints inherent in the development of any defense system, it is important to consider national security prior to deployment, as well as post-deployment. Defense should nominally be considered as the level of security that can potentially be provided by each alternative.

Budgetary Impact. Each policy will be evaluated on its potential budgetary effects on discretionary spending at the federal level. A low budgetary impact will assume that there will be little to no change in the discretionary budget for defense.

Non-Proliferation Efforts. Any NMD policy should not neglect its affect on global non-proliferation efforts. Both the United States and Russia have thousands of nuclear weapons that are not necessary in a post-Cold War era. Their continued efforts at reductions are important to promote world peace. Any policy should be structured to guarantee further cuts in nuclear arsenals. The ABM treaty has served as the cornerstone for strategic weapons reductions for almost three decades. Other pacts such as the 1991 Strategic Arms Reduction Treaty (START I) and the 1993 Strategic Arms Reduction Treaty (START II) have also served as useful tools to help guide non-proliferation efforts. Certain steps to increase national security may be seen as a violation of these treaties, thus curtailing the ability of the United States to lead nuclear stabilization efforts.

Administrative and Technological Feasibility. The administrative and technological feasibility associated 


\section{POLICY PERSPECTIVES}

with each proposed defense policy is a reflection of the government's ability to procure a viable system. The technological and administrative constraints that currently exist and the scientific barriers to deployment are important considerations. Without credible technology, any defense system will be unreliable. Technological feasibility is crucial to the selection of any defense alternative. The scientific and the defense communities are deeply divided in their assessments of the available options. The dynamic nature of scientific advancement makes it necessary to discuss the short-term and longterm implications of each alternative. Administratively, any change in defense policy will require dramatic structural changes in existing systems.

Political Feasibility. The political feasibility of a policy will be evaluated by its ability to remain viable under the pressures of the political process. Political feasibility is relevant in defense policy due to the high degree of cooperation that must exist between the legislative and executive branches. Both branches are essential to successful policy implementation. Generally, defense policy generates greater bipartisanship. However, the methods for preserving national security have become more fractious since the end of the Cold War. The absence of an overt threat makes shaping policy more challenging. A national missile defense system would require concessions by both sides, and its construction would span several administrations.

\section{Status Quo Defense Proposal}

Maintain the nation's current level of strategic

missile defense.

The United States Government, since the height of the Cold War, has advocated deep reductions in its' nuclear arsenal. Many defense experts believe that at current levels this nuclear arsenal creates counterproductive results. Advocates of deep weapons reductions, such as
Theodore Postol, a scientist at the Massachusetts Institute of Technology, and James Goodby, a non-resident scholar at the Brookings Institute, state: "U.S. policy clings to Cold War concepts that emphasize the importance of constantly standing ready to deliver a quick and massive attack against opposing nuclear forces." ${ }^{\prime 1}$ This mentality threatens global stability and could possibly spur another arms race. The same defense theorists claim that: "Such policies (mutual deterrence and hair-trigger response) are misguided. The overriding goal of U.S. policy should be to prevent the use, threat of use, or further spread of nuclear weapons. ${ }^{2}$

Fundamentally, the deployment of further defense measures could have the adverse affect of spurring fledgling nuclear nations to increase their arsenals. Preserving the status quo could allow the United States to retain its role as a superpower and continue pressing for global adherence to policies of non-proliferation. National security may be compromised if the United States is not able to effectively assess the intentions and resources of the nations that pose the greatest threat. The next administration must be able to properly balance the need to uphold a strong defense with the possibility that their actions could jeopardize a relatively peaceful current state of world affairs.

National Defense Impact. This policy, if advocated by the next administration, essentially dismisses the need for a national missile defense system. Proponents of the status quo maintain that the current threat posed to the United States does not require the construction of any strategic missile defense initiatives. Maintaining the status quo would not necessarily neglect national security needs; rather, it would rely on conventional weaponry and current nuclear forces to dissuade an intercontinental ballistic missile attack. Furthermore, supporters of the status quo rely on the premise that, "for half a century, nuclear war has been avoided thanks to deterrence and 


\section{IS DEPLOYMENT DESIRABLE?}

the notion that striking first held out little attraction because the other party could and would retaliate with devastating consequences. ${ }^{\prime 3}$ The prospect of retaliation by American forces has served as a deterrent to attack for many years. Thus, despite the increased threat from rogue nations and terrorists, military dominance may be enough to ensure national security. Scholars who dis* miss the threat from rogue states believe that the prospect of U.S. retaliation is the key to current defense policy. "With respect to North Korea, Iran, and Iraq, it is not clear how soon a combined threat to the United States from ballistic missiles and weapons of mass destruction could arise. However, the use of such weapons would be strongly deterred by the threat of retaliation. ${ }^{.4}$

Skeptics of missile defense, such as Senators Joseph Biden (D-DE) and Paul Wellstone (D-MN), and prominent organizations like the Carnegie Endowment for International Peace, do not deny the growing missile strike threat. However, they advocate more globally coordinated methods to address the threat, such as multi-lateral disarmament. The long-term threat of attack potentially creates a problem for U.S. strategists. Missiles will eventually be able to span significant distances, rendering the continental United States vulnerable. The threat of retaliation is no guarantee against a limited attack. As weapons technology becomes more readily available, the threat of a missile attack will continue to grow. If the U.S. continues to utilize its nuclear arsenal as a deterrent, the government must continue an active role in global non-proliferation efforts and pursue diplomatic relations with potentially hostile states.

Budgetary Impact. The status quo would require a minimal increase in defense discretionary spending levels, if any at all. Maintaining the current level of national security will only require budget expenditures associated with normal baseline provisions for defense.

Non-Proliferation Efforts. Without the deployment of any overt defensive mechanisms, such as a National Missile Defense system, there is no reason to believe that current non-proliferation efforts would decrease. Preserving the tenets of the ABM and START Treaties, which primarily require the United States and Russia to reduce their nuclear arsenals, is of great importance if the status quo is maintained. Substantive global non-proliferation efforts would supplement U.S. national security efforts. If the United States aggressively pursues NMD, the government will find it difficult to champion non-proliferation efforts. Specifically, deployment could be construed as a violation of the ABM Treaty and would jeopardize further arsenal reductions.

Both opponents and proponents of a strong national defense have argued the legality and applicability of the ABM Treaty in a post-Cold War era. Several legal scholars contend that the provisions in the ABM Treaty are no longer legally binding. They assert that the treaty died with the dissolution of the Soviet Union. However, many politicians and scholars still believe that the ABM Treaty plays a vital role in securing a more cooperative relationship with Russia, and acts as a benchmark for continued weapons reductions. In recent months, President Clinton has engaged in dialogue with Russian President Vladimir Putin to reach an agreement that could amend the ABM Treaty to allow for a limited defense system. This tenuous step toward providing for a defense system would, if agreed upon, allow non-proliferation efforts to continue.

Some members of Congress have voiced concern over changes to, or abandonment of, existing treaties. "They [certain members] believe that the Administration's new intention to negotiate $\mathrm{ABM}$ amendments could undermine the offensive arms control process - they argue that the remaining Russian missiles pose a greater threat to the United States than potential missiles from rogue nations." ${ }^{5}$ The details of the $A B M$ treaty are vague, 
but any attempt to alter the existing language could provoke Russian officials. If these amendments are sought, the State Department must be prepared for the potential negative consequences of such an action. It will be incumbent upon the next administration to decide the residual effects of abrogating or violating existing accords on non-proliferation.

Administrative and Technological Feasibility. This policy will have little to no effect on current administrative practices. No technological changes in current defense policy would be required. It should be assumed that the military would continue to provide the same level of defense through normal procurement procedures.

Political Feasibility. The prospect of constructing a NMD system has gained political support from both Republicans and Democrats. Traditionally, Reagan Republicans have been proponents of increased defense spending. Since the 1980s, they have supported efforts to develop a missile defense system. Reinforced in the "Contract with America," developing a missile defense system remains a primary objective for Republicans. Their reasoning for building a missile defense was strengthened with the release of the Rumsfeld Commission Report. The report concluded that rogue states would shortly be able to launch a missile capable of reaching the U.S. Proponents for NMD feel that the government would be negligent to maintain the status quo, and conclude that any defense is better than no defense at all. In addition, "the uncertainties related to the command and control of former Soviet Nuclear forces have led some in Congress to call for accelerated efforts to develop and deploy a national missile defense system to protect against the threat of accidental or unauthorized ballistic missile launch." ${ }^{6}$ Democrats, recognizing the possible threat, are not as ardently opposed to NMD as they once were. But, many Democrats still favor continued arms reductions to a national missile defense.
Defense policy decisions remain a contentious issue in Congress. Basic philosophical differences have prompted legislative gridlock. Addressing the issue in a divided government has polarized the factions. If one party assumes control of the legislative and executive branches the possibility of deployment may increase. But, even if the executive and legislative branches are of the same party, the majority lead in Congress is so slim that major policy changes are doubtful. In the Senate, procedural barriers can make it virtually impossible to pass legislation without bi-partisan efforts. Recognizing the government's predilection toward incremental policy change makes retaining the status quo policies quite likely.

\section{Limited Missile Defense System}

The limited alternative advocated by those who feel the United States should explore possible NMD options.

"A limited NMD, which would afford the United States protection against long-range ballistic missile threats from rogue states, is feasible and probably can be deployed at a reasonable cost." 7 The Clinton administration has recently begun to advocate for the deployment of a limited missile defense shield. "The Administration's planned program for national missile defense (NMD) is designed to defend the entire United States from attack by a relatively small number of incoming ballistic missiles." ${ }^{\prime 8}$ Initially opposed to any effort to deploy a national missile shield, the Clinton administration has recognized new international threats. However, the final decision regarding NMD has been left for the new administration. Increased political and public support for NMD and the realization that the United States might be susceptible to an attack has elicited heightened political awareness for the issue. Former Secretary of Defense William Cohen acknowledged that, "there is a threat, and the threat is growing, and it will soon pose a danger to Americans here at home." "Subsequently, Presi- 
dent Clinton signed legislation to advance the exploration of missile defense deployment. Essentially, the law states it is the intention of the U.S. Government to deploy a missile defense system, capable of protecting our nation's territory, as soon as it is technologically possible. The vague language contained in this law was intentional. It recognizes the possible need for a NMD system, but does not commit U.S. defense resources to a project that has not yet been proven.

National Defense Impact. Any plan to deploy a limited national defense system. would create a defense mechanism that does not currently exist. The United States does not posses any countermeasure capable of intercepting an enemy missile. If the new administration goes forth with a NMD system, it could provide an upgraded level of national security.

The limited NMD would not be capable of protecting the U.S. against a sizable attack. The Clinton administration believed a limited defense "can go a long way toward immunizing America against attack-at least from missiles launched by North Korea, Iran and Iraq, which are known to be developing intercontinental missiles. " ${ }^{10}$ However, the proposed system would do nothing to deter or to defend against a possible large-scale strike. The Russians would still be able to overwhelm this defense system with their current arsenal. However, foreign policy experts agree that the possibility of Russia intentionally launching a major strike against the U.S. is almost nil. An accidental launch, on the other hand, could be provoked by errors in Russian tracking equipment. Russia's faltering economy and fractured military may lead to an inability to safely maintain the arsenal.

Fortunately, the leaders of the two countries have taken steps to share vital information to prevent future mistakes. The limited missile defense system could guard against the threat from communication breakdowns. For the time being, a limited national defense system could provide a safeguard against aggressors, other than Russia, and perhaps the Chinese. The Chinese are rapidly developing a nuclear arsenal and within a few years may have an arsenal capable of overwhelming a limited defense system.

Budgetary Impact. The proposed construction of a limited defense system has lower short-term costs than potential long-term costs. This is due to the relatively lengthy period that would be necessary to construct such a system. Annual discretionary spending levels would increase and the accrued costs over years of development could constitute significant outlays. The proposed limited NMD system has been broken down into 3 stages of deployment. Although construction can be halted at any point during the three stages, upon full completion, the Congressional Budget Office ( $\mathrm{CBO}$ ) estimates that by the year 2015 the government will have spent $\$ 49$ billion on NMD. ${ }^{11}$ Although estimates are often imperfect, it appears that the costs associated with the deployment of a NMD could be significant. The proposed system, although limited by design, will require additional revenue sources or cuts in other discretionary programs, assuming PAYGO (pay as you go) budgeting is applied.

Non-Proliferation Efforts. The deployment of a missile defense system could nullify the ABM Treaty. The treaty specifically prohibits the construction of a missile defense system protecting the entire nation against attack. The only allowance made for missile defense is a regionally targeted system that would only protect the nation's capital against attack. Russia currently has such a system in place; the United States does not. If the next administration decides that the United States' inclusion in the $\mathrm{ABM}$ Treaty is no longer in the national interest, the U.S. government must give six months notice to officially dissolve the treaty. The Clinton administration has attempted to negotiate new treaty terms with the Russians. It does not appear, at least for now, that they are 
willing to accept any change that would allow the United States to build a missile defense system. Both sides are sharply divided about the role that the ABM Treaty should play in the decision to go forward with the system. "If NMD enthusiasts regard the ABM Treaty as the obstacle to achieving American security, committed arms controllers see it as a bulwark against unchecked arms races and nuclear Armageddon." 12 The two camps have exhibited tremendous rigidity and are not quick to concede any ground to the other side. This division displays the obstacles in achieving two national goals that are seemingly contradictory. Increased national security may come at the expense of global non-proliferation. Deploying a NMD system could have the adverse effect of instigating a new arms race.

Any deployment by the United States must address the Chinese government's concerns. The Chinese have been developing a nuclear arsenal for decades. The Chinese government could perceive a U.S. missile shield as a threat, causing an increase in weapons production, potentially threatening regional stability. Southeast Asia, already a volatile region, could become more dangerous. The Indian government views the Chinese as a threat to their national security. Pakistan and India are embroiled in a struggle over Kashmir. Decades of bitter conflict suggest that peace in the region will not happen soon. A regional arms race is possible. The United States could have a profound impact on non-proliferation efforts in this region if the proper steps are taken. It is in the U.S. Government's interests to assure Russia and China that a NMD system would not be intended to compromise their nuclear arsenals.

Administrative and Technological Feasibility. The technological feasibility of any missile defense system has yet to be conclusively proven. Since the days of Reagan's "Star Wars" plan, the military has taken significant steps to develop technology that could intercept an enemy missile headed toward the U.S. Still, many questions remain about the reliability of such a system. Some independent scientists have maintained that the government is still several years away from establishing a defense system that could be effective against an attack. The evidence seems to support their skepticism. The United States government has administered three NMD tests. Only one of the three has had any success. The two failures have produced doubts that the Pentagon will be able to effectively deploy even a limited missile defense. Top officials, such as former Joint Chiefs of Staff chairman Gen. John Shalikashvili and former CIA director John Deutch have urged the administration to delay any deployment decisions. A few reasons they cite are: "the many technical questions hanging over the system, predictions that a U.S. missile shield could provoke an arms race in Asia, and concern about souring relations with Russia and the European allies." ${ }^{13}$ It certainly would be an error to dissolve any existing treaties so that the United States could go forward with a system that is riddled with technological flaws. However, military officials and industry developers believe that they are close to correcting the flaws in the system that caused the initial interceptor failures.

Administratively, the burden that could arise from deployment is significant. Even a limited system would require a tremendous amount of manpower to operate. The contracting and construction that would be necessary to build the system would require extensive human resources. The required bureaucracy resulting from a NMD system could fundamentally change many Pentagon operations.

Political Feasibility. "A political consensus now exists in America that such a limited system provides a necessary answer to the emerging ballistic missile threat from the so-called rogue states of North Korea, Iran and Iraq. ${ }^{14}$ The centrist Clinton administration finally endorsed the 
deployment of a limited system. This approval gave NMD advocates a new ally in their quest to procure a viable missile shield. With the President's signature, certain moderate Democrats were able to endorse NMD, giving the system bi-partisan support. Arms reductions proponents, many liberal Democrats, maintain that the proposed system will do nothing but disturb the nonproliferation regime that the United States has been fostering for many years. Defense-minded politicians have also been blessed with public support for NMD. The increased threat of an attack against the United States has made garnering a limited national missile defense system a more attractive alternative to the general public. Growing consensus will create a ripe environment for deployment.

\section{A Comprehensive Míssile Defense System}

Officials who believe that a modest missile defense system will not be sufficient in maintaining our national security back the comprehensive alternative.

The more comprehensive plan advocated by President-elect Bush and congressional Republicans, avid missile defense supporters, is very ambitious. According to these politicians: "Our missile defense must be designed to protect all 50 states-and our friends and allies and deployed forces overseas-from missile attacks by rogue nations or accidental launches. ${ }^{15} \mathrm{Re}$ publicans have not released specific details of their plan, but they contend that it is vital to U.S. national security interests to aggressively pursue a broad missile defense shield. The shield proposed by the Clinton/Gore administration and several moderate congressional members would consist of land-based interceptor missiles. The comprehensive system includes land-based missiles, but also may utilize sea-based and space-based missiles to ensure greater coverage. The system envisioned by many defense-minded Republicans is reminiscent of the plan endorsed by President Reagan. Bush has worked closely with his foreign policy advisors to create a plan that he feels is more able to match our nuclear security needs to the emerging dangers of a new age.

National Defense Impact. The comprehensive alternative provides for substantial fortification of U.S. national security. An effective multi-tiered system would be able to repel multiple warheads. Optimally, the comprehensive plan would even provide for the safety of troops and allies overseas. Additionally, Bush has noted that: "threats also come from insecure nuclear stockpiles and the proliferation of dangerous technologies. Russia itself is no longer our enemy. The Cold War logic that led to the creation of massive stockpiles on both sides is now outdated. Our mutual security need no longer depend on a nuclear balance of terror. ${ }^{16}$ Proponents recognize the existence of a real threat. The short-term impact of deploying a comprehensive NMD could pose a significant threat to the United States. The construction of such a system would take considerably longer than the limited system, thus creating a longer period of time between ending the ABM Treaty and system readiness. This window of uncertainty could provide a potential aggressor the opportunity to strike when the United States is vulnerable to attack. Despite these limitations, if the system is functional and accurate, long-term security is strengthened.

Budgetary Impact. The potential for an increase in the defense department's discretionary spending levels is substantial. There have not been any estimates of the cost of such a comprehensive system, but it stands to be significantly higher than the price tag associated with the limited defense alternative. Considering the ambitious nature of the Republican plan, major budgetary priority shifts may have to be made to accommodate the system. 
Non-Proliferation Efforts. Considering that Bush and several conservative foreign policy strategists feel that the ABM Treaty is a relic from the Cold War, it appears that several treaties would be in danger if this alternative were employed. It is possible that other nonproliferation efforts will be substituted for the ABM and START Treaties, but it is difficult to speculate what possible accords may be reached. Bush has advocated unilateral arms reductions by the United States, coupled with the deployment of a missile shield. The practicality of these suggested reductions raises many strategic questions. Bush recently stated that: "the United States has an opportunity to lead to a safer world, both to defend against nuclear threats and reduce nuclear tensions. It is possible to build a missile defense and defuse confrontation with Russia. America should do both"17 Many Republicans have expressed optimism about the prospect of achieving these seemingly contradictory goals, but one must be skeptical of the United States' ability to successfully execute both. The Russians may decide to amend the ABM Treaty, but a defensive build-up potentially serves as a catalyst for an emerging arms race with the recalcitrant Chinese and other hostile nations.

Administrative and Technological Feasibility. Currently, the technology does not exist to sustain a reliable limited national missile defense system, much less a comprehensive system. It is reasonable to assume that the scientific capability to deploy a workable land, sea, and space-based defense system will exist in the near future. However, defense analysts have yet to analyze the comprehensive alternative because it has not been elucidated. If the possibility of constructing a comprehensive defense system gains support, the scientific community will certainly begin to analyze and criticize the defined system. Many questions will surface about the effectiveness of such untested technology. The potential for significant administrative burden to be placed on the Pentagon from the implementation of a complicated system would be expected.

Political Feasibility. The political consensus exists to begin the deployment of a national missile defense system, although the nature of the system could cause even greater division over the issue. Democrats who currently support a limited NMD system might be hesitant to vote for a system that could be wrought with technical and budgetary pitfalls. Without bi-partisan support, it would be difficult to sustain the program over many years with numerous shifts in political power. Any efforts to increase national defense must appeal to the centrist elements of both political parties. The maintenance of a strong national security resonates well with the public, but the deficits created during the Reagan era could prevent the comprehensive plan from gaining broad support. The plan does not have much chance for survivability if the two dominant parties maintain their uncompromising positions.

\section{Conclusion}

The complexity of the debates surrounding a U.S. National Missile Defense system makes any agreement seem impossible. However, the three policy options outlined in this paper provide a starting point for discussion. The broad-based approach that has been taken to assess each policy can be used to help provide a framework for the important issues surrounding NMD. The audience can decide what issues are most important; those of political or administrative feasibility, cost, foreign relations, or impacts on national security. National defense policy is not a topic that can be placed on the "back-burner" while the volatile U.S. political climate settles. Terminating, or even delaying, the deployment of a NMD could be critical.

Policy making in the United States is not designed to be a fluid process. The Constitution sets forth proce- 


\section{IS DEPLOYMENT DESIRABLE?}

dural barriers and separate, but co-equal, branches of government to ensure well-contrived laws. The $107^{\text {th }}$ Congress will be one of the most equally divided in our nation's history. The House Republicans maintain a slight majority, but this tenuous majority will make it difficult to craft legislation. The parties are divided amongst themselves, creating an almost impossible environment for consensus building. The more collegial Senate may find itself in an even more precarious situation. The filibuster, a procedural tactic employed by a Senator to block passage of legislation, will be almost impossible to overcome. Sixty Senators would be required to invoke cloture and defeat the filibuster. Controversial pieces of legislation, such as measures promoting a national missile defense, would require significant party defections. This is not a likely scenario, given the vitriol between the parties. Further, the election did not provide the incoming President with a mandate to propose radical policies.

Defense policy is especially difficult to administer. Not only do politicians have to concern themselves with local and national effects, they must be aware of the global impact of their decisions. The U.S. Government's decisions on NMD could substantially affect relations with other nations and prompt new global sentiments against arms reductions. The Senate has already rejected the Comprehensive Test-Ban Treaty, seen by many nations as a U.S, rejection of further arms reductions. Pursuing a national missile defense could prompt a new arms race. The ${ }^{18}$ next administration must address the challenges of maintaining a strong national defense and continuing U.S. global military technological superiority, while preserving the ability to significantly reduce the threat of foreign nuclear arsenals. It will be extremely important to promote sound foreign policy through active engagement with those nations most likely to be affected by U.S. defense decisions.
While this debate is likely to continue for years, it would be negligent of U.S. politicians to stand idle and take no action. The national security of the United States could be in jeopardy if the status quo is maintained. Should the U.S. Government not immediately embark on the more prudent route of diplomacy and non-proliferation, they should be fully prepared to engage in NMD deployment and be confident that it works. Aggressors will not sit patiently by and wait for a decision.

\section{Notes:}

' Harold A. Feiveson, The Nuclear Tuming Point: A Blueprint for Deep Cuts and De-Alerting of Nuclear Weapons, (Washington, DC: The Brookings Institution Press, 1999), 29.

${ }^{2}$ Ibid

${ }^{3}$ Richard Haass, "The New Nuclear Thing," 1 June 2000. <http:// www.brookings.org/views/op-ed/haass>

${ }^{4}$ Feiveson, 18

5 Amy F. Woolf, National Missile Defense and the ABM Treaty: Overview of Recent Events. CRS Report for Congress, (19 March 1999): CRS-3

${ }^{6}$ National Security Report, Unveiling the Ballistic Missile Threat: The Ramifications of the Rumsfeld Report. <http://www,house.gov/ nsc>

${ }^{7}$ Charles V. Pena, National Missile Defense: Examining the Options. (Washington, DC: The Cato Institute, 1999), 1.

${ }^{8}$ CBO Papers, Budgetary and Technical Implications of the Administration's Plan for National Missile Defense. (April 2000): 1.

Woolf, CRS-3

10 William J. Broad, 30 June 2000, "A Missile Defense With Limits: The ABC's of the Clinton Plan." The New York Times, (30 June 2000): 1. <http://www.nytimes.com>

${ }^{11}$ CBO Studies and Reports, "Budgetary and Technical Implications of the Administration's Plan for National Missile Defense." April 2000

${ }^{12}$ Ivo H. Daalder. Deploying NMD: Not Whether; but How. (Washington, DC: Brookings Institution Press, 1999), 18.

${ }^{13}$ Roberto Suro, "More Doubts are Raised on Missile Shield," The Washington Post, (18 June 2000): A16.

14 Daalder, 1.

${ }^{15}$ George W. Bush, "Missile Defense Now," The Washington Times, (25 May 2000), Op-Ed. 
${ }^{16}$ Ibid

${ }^{17}$ George W. Bush, Excerpts from Bush's Remarks on National Security and Arms Policy, quoted in The New York Times (24 May 2000).

\section{References}

Babington, Charles. "U.S. Set to Share Its ABM Research." The Washington Post 1 June 2000.

Broad, William J. "Antimissile Testing Is Rigged to Hide a Flaw, Critics Says." The New York Times 9 June 2000.

"A Missile Defense With Limits: The ABC's of the Clinton Plan." The New York Times 30 June 2000.

Brown, Harold. "Is Arms Control Dead?" Washington Quarterly, (Spring 2000).

Bush, George W. "Missile Defense Now." The Washington Times 25 May 2000.

Cambone, Stephen, "An Inherent Lesson in Arm Control." Washington Quarterly, (Spring 2000).

"Cohen Delays His Finding on Building Missile Radar." The New YorkTimes 8 August 2000.

Congressional Budget Office: Budget Options for National Defense (March 2000).

CBO Papers: Budgetary and Technical Implications of the Administration's Plan for National Missile Defense. (April 2000)

Congressional Record, Statement by Senator Joseph Biden, 25 May 2000.

Congressional Record, Statement by Senator Thad Cochran, 9 June 2000.

Congressional Research Service Info Pack - Ballistic Missile Defenses, IP 496B.

Cordesman, Anthony H. "Where the Money Goes in 'Homeland Defense': Spending on National Missile Defense and Counter-Terrorism: A Graphic and Tabular Analysis." The Center for Strategic and International Studies Press. 12 July 2000.
Daalder, Ivo H., James M. Goldgeier, and James M. Lindsay. "Deploying NMD: Not Whether, But How" Washington, DC: The Brookings Institution Press, 2000.

Excerpts from Bush's remarks on National Security and Arms Policy. <http://www.nytimes.com/library/ politics/camp/052400wh-bush-text.html .

Farley, Christopher. "May the Shield be With You." Time Magazine 10 July 2000.

Feiveson, Harold A. The Nuclear Turning Point: A Bluprint for Deep Cuts and De-Alerting of Nuclear Weapons. Washington, D.C.: Brookings Institution Press, 1999.

King Jr., Neil. "Antimissile Shield Flawed, Scientists Set to Tell Congress." The Wall Street Journal 12 June 2000 .

Kingdon, John W. Agendas, Alternatives, and Public Policies, 2nd edition. New York, NY: HarperCollins Publishers, 1995.

Kirkpatrick, Jeane J. "Target America: The Need for a Missile Defense System." Washington, DC: AEI Press, 1999.

Gordon, Michael R. "Russian Officials Flesh Out Alterna tive Antimissile Proposal." The New York Times 14 June 2000.

Graham, Thomas. "Strengthening Arms Control." Washington Quarterly, (Spring 2000).

Haass, Richard N. "The Nuclear Thing." $<$ http://www.brookings.org $>$.

Hoffman, David. "Russia 'Blind' to Attack by U.S. Missiles." The Washington Post 1 June 2000.

LaFraniere, Sharon. "Russian Threatens Action Over U.S. Missile Plan." The Washington Post 23 June 2000.

Library of Congress. Website for the Legislative Branch. $<$ http://thomas.loc.gov>.

Marquis, Christopher. "Cohen Says Missile Defense System Requires Support of Allies." The New York Times 26 July 2000 .

Myers, Steven Lee, "U.S. Missile Plan Could Reportedly Provoke China." The New York Times 10 August 2000. 


\section{IS DEPLOYMENT DESIRABLE?}

National Security Report, "Unveiling the Ballistic Missile Threat: The Ramifications of the Rumsfeld Report." Washington DC, 1998.

O'Hanlon, Michael. "Star Wars Strikes Back." Foreign Affairs (November/December 1999).

Pena, Charles V. National Missile Defense: Examining the Options. Washington, DC: The Cato Institute Press, 1999.

Ricks, Thomas E. "Pentagon May Back Missile Shield Even if Test Fails." The Washington Post 21 June 2000.

Rushefsky, Mark E. Public Policy in the United States: Toward the 21st Century, $2^{\text {nd }}$ ed. Belmont, CA: Wadsworth Publishing Company, 1996

Schlesinger, James. "The Demise of Arms Control?" Washington Quarterly, (Spring 2000).

Schmitt, Eric, and Steven Lee Myers. "Clinton Lawyers Give a Go-Ahead to Missile Shield." The New York Times 15 June 2000.

Sciolino, Elaine. "U.S. Study Reopens Division Over Nuclear Missile Threat" The New York Times 5 July 2000.

Scoblic, Peter. "What About China?" The New York Times 9 June 2000.

Suro, Roberto. "Sea-Based Missile Defenses Supported." The Washington Post 27 May 2000.

U.S. Congress website. <http://congress.gov>.

Wayne, Leslie. "After High-Pressure Years, Contractors Tone Down Missile Defense Lobbying." The New York Times 13 June 2000. 
